\title{
The Influence of Macroeconomic Environment on Australian Household Debt: An Application of Dynamic OLS
}

\author{
Xianming Meng \\ Institute for Rural Futures, University of New England, Armidale, Australia \\ Email: xmeng4@une.edu.au
}

How to cite this paper: Meng, X.M. (2016) The Influence of Macroeconomic Environment on Australian Household Debt: An Application of Dynamic OLS. Open Journa of Social Sciences, 4, 1-25.

http://dx.doi.org/10.4236/jss.2016.41100

Received: August 12, 2016

Accepted: November 22, 2016

Published: November 29, 2016

\begin{abstract}
Concerns about household debt increase with the escalating debt level in developed countries. Australia is a good example of this. This paper applies the dynamic ordinary least square (DOLS) method to explore the determinants and influences of Australian household debt. The results show that the rising Australian household debt results from the increased size of the economy, a booming housing market, a favourable macroeconomic environment and favourable government policies. Although the rising household debt stimulates economic growth in the short run, it may induce economic instability in the long run.
\end{abstract}

\section{Keywords}

Australian Household Debt, Dynamic OLS, Housing Prices, Interest Rates

\section{Introduction}

Australian household debt grew rapidly in the early 1990s and by the turn of the century Australians were amazed by the acceleration in debt levels. This phenomenon has attracted enormous attention and has generated heated arguments, both within and outside of Australia. Concern has been expressed about the rapid rise in Australian household debt from time to time (e.g. reference [1] and [2]), but others have taken a more optimistic view. For example, reference [3] claimed that the financial position of Australian households was within a serviceable range according to the debt-service and gearing ratio. The 2008 global financial crisis has demonstrated the seriousness of controlling the growth of household debt and thus silenced the argument. The growth of Australian household debt is now slowing down and appears less worrying, but it seems 
more pertinent than ever to identify the factors that affect Australian household debt.

The remainder of the paper is organised as follows. The next section reviews previous studies. Section 3 provides a financial investigation of Australian household debt. The purpose of Section 4 is to specify and estimate the empirical model at macroeconomic level. Section 5 interprets the main findings from the empirical model while Section 6 summarises the main conclusions.

\section{Previous Studies}

Prompted by rising Australian household debt, some institutions have included household debt information in their surveys or have initiated surveys on this topic. For example, the Australian Bureau of Statistics (ABS) has conducted a few waves of survey on Household Expenditure (HES), and it recently created the household balance sheet in the national accounts. Melbourne University started the Household, Income and Labour Dynamics in Australia (HILDA) Survey (funded by the federal government) in 2001 and has already completed 8 waves. The Reserve Bank of Australia (RBA) finished a survey in 2006 on Household Behaviour around Housing Equity. A number of studies at the household sector level have been based on these surveys: Reference [4] studied financial stress in Australia using the 1998-99 HES survey; reference [5], by employing a logit model and using the data from the HES and HILDA surveys, studied the factors that affect financial constraints of Australian households. Reference [6] used a bivariate and logit model to analyse the data obtained by surveys on Household Behaviour around Housing Equity.

At the macro level, the RBA has published a number of papers and speeches on this topic. For example, reference [7] emphasizes the positive effect of low inflation on household borrowings. Reference [8] attributes the quick growth of personal credit to the innovations in products offered by banks, the increasing household preference toward the use of credit cards, and the continuing economic expansion with low inflation and low interest rates. Reference [9] illustrates the composition and distribution of household debt and suggests that low interest rates, the low inflation rate, and financial deregulations may have led to the rising household debt.

Other studies are in opinion similar to that of the RBA. For example, reference [10] suggests that the increase in household debt partly reflects increased house prices, due to the sustained low inflation and interest rates, and partly reflects the improved product choice and reductions in borrowing costs due to the deregulation of the financial sector in the 1980s and 1990s. Reference [3] claims the rising household debt level is due to the sustained boom in house prices and the sustainability of household credit depends on the growth of household disposable income and employment. Reference [11] takes a more Keynesian view since they argue that the government encourages private spending and the growth of household debt in order to sustain Australia's economic growth.

Researchers have compared household debts in different countries. Among them, reference [12] uses data across countries to analyse the possible determinants and the 
macroeconomic implications of rising household debt. According to reference [12], the rise of household debt reflects the response of households to lower interest rates and an easing of liquidity constraints. The increased household debt itself is not likely to be the source of negative shocks to the economy but will amplify shocks from other sources. Reference [13], in comparing the results of studies on household debt across countries, finds that the debt holding by age follows the life cycle pattern in all countries observed. Crook concludes that there are considerable variations in the determinants of desired stock of debt and in the marginal effects of household debt within, as well as between, countries.

All of these studies on Australian household debt are instructive, but they do have some limitations. One limitation is the emphasis they place on different individual aspects such as financial constraints, financial regulations, the effects of inflation and the effects of the interest rate, so they do not provide a complete picture on Australia household debt. A second limitation is that most studies provided only financial analyses on Australian household debt. To the best of author's knowledge, no one has yet estimated econometric models to find the determinants of Australian household debt at macro level. Based on data from the household accounts, microeconomic data from surveys and other macroeconomic data, this study intends to identify the determinants of Australian household debt by employing the dynamic ordinary least square (DOLS) method.

\section{A Financial Investigation about Australian Household Debt}

Before doing any modelling, it is useful to have a general grasp of Australian household debt. This section reveals the facts regarding the different aspects of Australian household debt: the development of Australian household debt over time, the funding sources, the composition and the distribution of Australian household debt.

\subsection{Evolution of Australian Household Debt over Time}

For any study on household debt, the proper measurement of household debt is a prerequisite. There are basically two types of measurement of household debt: the absolute and relative measurements. There are some advantages for each measurement, so we investigate the development of Australian household debt by each measurement in turn.

The absolute debt level: The absolute measurement gauges household debt in terms of currency. Its use is popular in household accounts and bank lending. For example, the household balance sheets use the absolute measurement, as shown in Table 1 .

A number of interesting facts can be gleaned from Table 1. The first is that during the period 1989 to 2008 household liabilities increased from $\$ 167.7$ billion to $\$ 1269.3$ billion. In spite of this, household debt levels remained well below total household asset levels. On this basis reference [15] Macfarlane's (2003) opinion was that the debt level was rather safe for the Australian macro economy. Secondly, total household assets increased faster than debts, so net wealth has been growing. However, since the downturn 
Table 1. Summary of Australian household sector balance sheets, A \$ billion (As at 30 June).

\begin{tabular}{|c|c|c|c|c|c|c|c|}
\hline Year & Housing assets & $\begin{array}{l}\text { other non-financial } \\
\text { assets }\end{array}$ & Non-financial assets & Financial assets & Total Assets & Liabilities & NET WORTH \\
\hline Jun-1989 & 334.8 & 595.7 & 930.5 & 459.6 & 1390.1 & 167.7 & 1222.4 \\
\hline Jun-1991 & 391.4 & 633.5 & 1024.9 & 525.8 & 1550.6 & 194.6 & 1356.0 \\
\hline Jun-1994 & 448.5 & 705.7 & 1154.2 & 673.4 & 1827.6 & 236.6 & 1591.1 \\
\hline Jun-1995 & 476.1 & 744.8 & 1220.9 & 705.5 & 1926.4 & 266.9 & 1659.5 \\
\hline Jun-1996 & 495.6 & 782.8 & 1278.4 & 754.4 & 2032.9 & 299.9 & 1733.0 \\
\hline Jun-2000 & 632.5 & 1170.1 & 1802.6 & 1116.8 & 2919.4 & 473.3 & 2446.1 \\
\hline Jun-2001 & 728.0 & 1233.1 & 1961.1 & 1218.5 & 3179.6 & 515.5 & 2664.2 \\
\hline Jun-2002 & 774.5 & 1505.0 & 2279.5 & 1274.3 & 3553.8 & 596.3 & 2957.5 \\
\hline Jun-2003 & 851.9 & 1740.1 & 2592.0 & 1339.7 & 3931.7 & 684.9 & 3246.8 \\
\hline Jun-2004 & 947.2 & 2068.3 & 3015.5 & 1489.9 & 4505.3 & 800.4 & 3704.9 \\
\hline Jun-2005 & 1038.6 & 2163.0 & 3201.6 & 1672.8 & 4874.5 & 904.5 & 3970.0 \\
\hline Jun-2006 & 1121.0 & 2395.2 & 3516.2 & 1971.3 & 5487.5 & 1018.0 & 4469.6 \\
\hline
\end{tabular}

Source: Reference [14].

in 2000 the increase in total assets has slowed. A third feature is that non-financial assets are a major component of household assets. Examination of the household balance sheet reveals that the bulk of non-financial assets is housing related, such as the value of dwellings and land.

Although absolute measurement can provide us with a reasonable indication of household debt it can sometimes be misleading. Because the size of the economy grows over time, the magnitudes of the economic variables linked with the size of the economy also tend to increase with time. Therefore, comparisons of the absolute value over time will be biased by the size of the economy. Relative measures of household debt circumvent this bias. The popular relative measurements are the debt-income ratio and the gearing ratio.

The debt-income ratio: The household debt-income ratio measures household gross debts (liabilities) as a percentage of household gross disposable income. The last column in Table 2 indicates that the debt-income ratio has increased at an astonishing rate, more than doubling from 1990 to 2004. In 2005 the debt-income ratio reached 
Table 2. Household liabilities, GDP and disposable income, A \$ billion. (As at 30 June).

\begin{tabular}{|c|c|c|c|c|c|}
\hline Year & Liabilities & GDP & Disposable income & Liabilities as $\%$ of GDP & $\begin{array}{l}\text { Liabilities as \% of disposable } \\
\text { income }\end{array}$ \\
\hline Jun-90 & 187 & 385 & 265 & 48.6 & 70.6 \\
\hline Jun-00 & 473 & 624 & 413 & 75.8 & 114.5 \\
\hline Jun-01 & 515 & 668 & 451 & 77.1 & 114.2 \\
\hline Jun-03 & 685 & 758 & 486 & 90.4 & 140.9 \\
\hline Jun-04 & 800 & 812 & 518 & 98.5 & 154.4 \\
\hline Jun-05 & 905 & 908 & 556 & 99.7 & 162.8 \\
\hline
\end{tabular}

Source: Reference [16].

$162.8 \%$. To put this into perspective, Australian households would have to work more than one and a half years just to pay back their debt.

The gearing ratio: The gearing ratio (household gross debt as a percentage of total assets) reveals the overall financial position of households. The last column in Table 3 illustrates that the gearing ratio has increased slightly over time (by $6.1 \%$ from 1990 to 2005 ) and that the overall gearing ratio is relatively low (less than 20\%). However, concluding that Australian household debt is at a safe level might be over optimistic, especially in the face of asset devaluation such as a stock market or housing market crash.

The gearing ratio may be understated as a consequence of the rapid rise of house prices in recent decades. As can be seen from the household balance sheets (Table 1), housing assets comprise a major part of household total assets. Housing assets may be overstated because of the rapid rise of house prices in recent decades. A fall in house prices would translate into a fall in the value of total household assets. As a result the gearing ratio would rise.

The gearing ratio obtained from the aggregate data also tends to downplay the risk of households. Total household assets include all households in Australia whereas total household debt relates only to those households with debt. As such, the aggregate gearing ratio may be substantially lower than the average gearing ratio for households with debt and thus underestimate the risk faced by indebted households.

\subsection{Composition of Australian Household Debt}

Figure 1 decomposes Australian household debt into three categories: owner-occupied housing debt, investment housing debt, and other personal debt. What is immediately noticeable from Figure 1 is that owner-occupier housing accounts for more than half of total household debt in the period under consideration. Another distinguishing feature is that debt associated with investment housing increases dramatically during the period, from less than $5 \%$ of disposable income in 1990 to more than $40 \%$ in 2008 . Thirdly, other personal loans increased only modestly. This debt breakdown is useful in ex- 
Table 3. Household liabilities and assets, A\$ billion. (As at 30 June).

\begin{tabular}{|c|c|c|c|c|c|}
\hline Year & Liabilities & Assets & Assets & Assets & -Liabilities as $\%$ of total assets \\
\hline Jun-90 & 187 & 994 & 500 & 1495 & 12.5 \\
\hline Jun-95 & 267 & 1221 & 706 & 1926 & 13.9 \\
\hline Jun-00 & 473 & 1803 & 1117 & 2919 & 16.2 \\
\hline Jun-02 & 596 & 2280 & 1274 & 3554 & 16.8 \\
\hline Jun-03 & 685 & 2592 & 1340 & 3932 & 17.4 \\
\hline Jun-04 & 800 & 3016 & 1490 & 4505 & 17.8 \\
\hline Jun-05 & 905 & 3202 & 1673 & 4875 & 18.6 \\
\hline
\end{tabular}

Source: Reference [14].

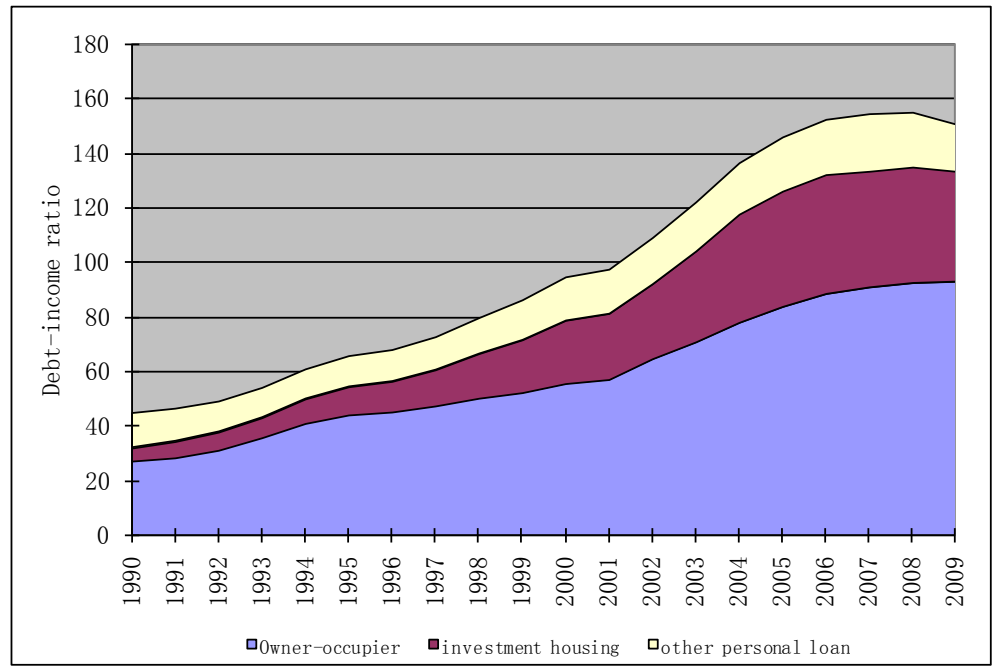

Figure 1. Composition of Australian household debt. Source: Reference [16].

plaining the high debt-income ratio and the low gearing ratio in the Australian household sector. The large amount of debt leads to a high debt-income ratio but the high percentage of mortgage debt secured on housing assets reduces the gearing ratio. Since housing assets have been highly inflated in recent years, the low gearing ratio does not guarantee the low risk of Australian household debt.

\subsection{Distribution of Australian Household Debt}

When we consider the risk of incurring household debt, how the debt is distributed is vital. Based on the data from the 2002 HILDA survey, this section outlines the distribution of Australian household debt. Since the main focus of this study is on the debt for Australian households at a national level, we only discuss the debt distribution by age and by income (wealth), not by state (region).

Distribution of household debt by income (wealth): the following table casts light on 
the overall distribution of household debt by income and by wealth.

The general conclusion of Table 4 is that the higher the income or wealth, the higher the debt. The richest households, the $91-100$ percentiles, owe nearly half of the total debt if sorted by wealth or $27 \%$ if sorted by income. The result is quite comforting in that it implies households may not be vulnerable to an adverse economic environment. However, there may be concerns for the middle class, especially the 51 - 60 through to the 71 - 80 percentiles. This group has small percentages of income and wealth but they undertake a considerably high percentage of debt.

Distribution of household debt by age: the distribution of household debt by age has an almost normal distribution as shown in Figure 2.

Table 4. The distribution of household assets and debts by wealth and income.

\begin{tabular}{ccccc}
\hline Percentile & \multicolumn{2}{c}{ Sorted by net wealth } & \multicolumn{2}{c}{ Sorted by net income } \\
\hline $1-10$ & Assets & Debts & Assets & Debts \\
$11-20$ & 0 & 0 & 5 & 2 \\
$21-30$ & 1 & 0 & 5 & 3 \\
$31-40$ & 2 & 1 & 5 & 5 \\
$41-50$ & 4 & 3 & 7 & 7 \\
$51-60$ & 5 & 5 & 7 & 8 \\
$61-70$ & 7 & 7 & 9 & 11 \\
$71-80$ & 9 & 9 & 10 & 16 \\
$81-90$ & 12 & 13 & 13 & 17 \\
$91-100$ & 18 & 18 & 15 & 27 \\
TOTAL & 42 & 45 & 25 & 100 \\
\hline
\end{tabular}

Source: Reference [17].

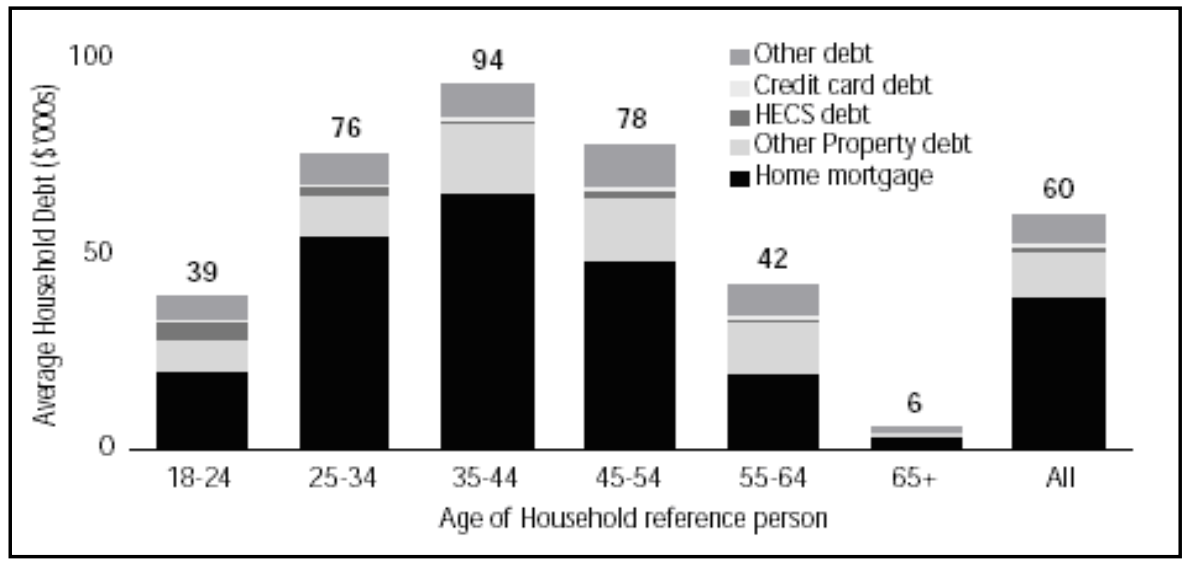

Figure 2. Household debt by age of household head and type of debt, 2002. Source: Reference [18]. 
One important message Figure 2 delivers is that the distribution of property debt is normal and its distribution largely determines the distribution of the total debt. This distribution is consistent with the Life-Cycle Hypotheses. However, since starting out, their wages are relatively low so they will borrow money to buy property and pay it off later. Another interesting aspect is that the HECS debt decreases with age, which is consistent with the HECS policy.

\subsection{Financing of Australian Household Debt}

The rising Australian household debt indicates that the desire of Australian household borrowing must have satisfied by the available funding sources, otherwise the borrowing cannot be realised. From the net lending by sector (Figure 3 ) we can conclude that some Australian household debt is directly funded by other domestic sectors.

Figure 3 shows, prior to 1986-87 the household sector in Australia was a net lender. From 1985-86 through to 1996-97 its net position changed several times. Since then it has been a net borrower, with borrowing increasing dramatically in recent times. Contrary to the household sector, the net position of the financial corporations sector changed in 1988-89 from net borrower to net lender. While the general government sector was also largely a net borrower, the non-financial corporations sector was a net borrower for the entire period as shown in Figure 3.

Based on the net lending positions of domestic sectors and the general lending practice in Australia, we can conclude that the household sector, as the largest borrower in recent years, have borrowed from the only private net lender-the financial corporations. However, part of this direct funding may come from investors overseas, because the aggregate net lending for all domestic sectors is negative for recent decades, which means Australia has been a net borrower for a long period of time (shown in Figure 4).

Figure 4 illustrates that, in aggregate, the domestic sector has been a net borrower over the past four to five decades. In 1979-80, net borrowing from overseas increased sharply from around $2 \%$ to $5 \%$. In subsequent years, it has fluctuated around $4 \%$. Net

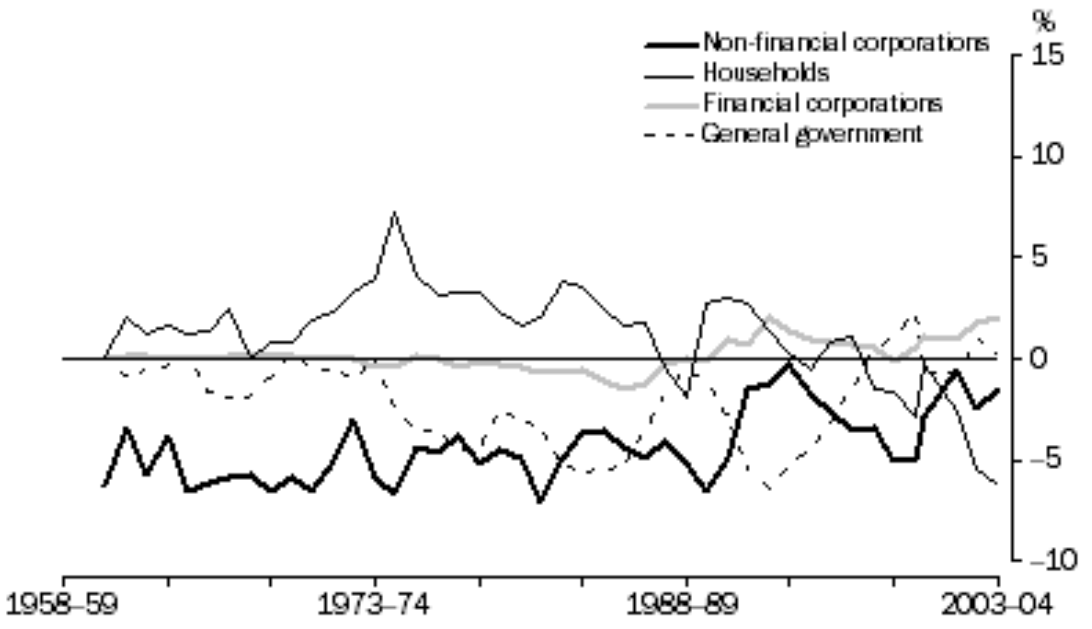

Figure 3. Net Lending by Sector-relative to GDP. Source: Reference [14]. 


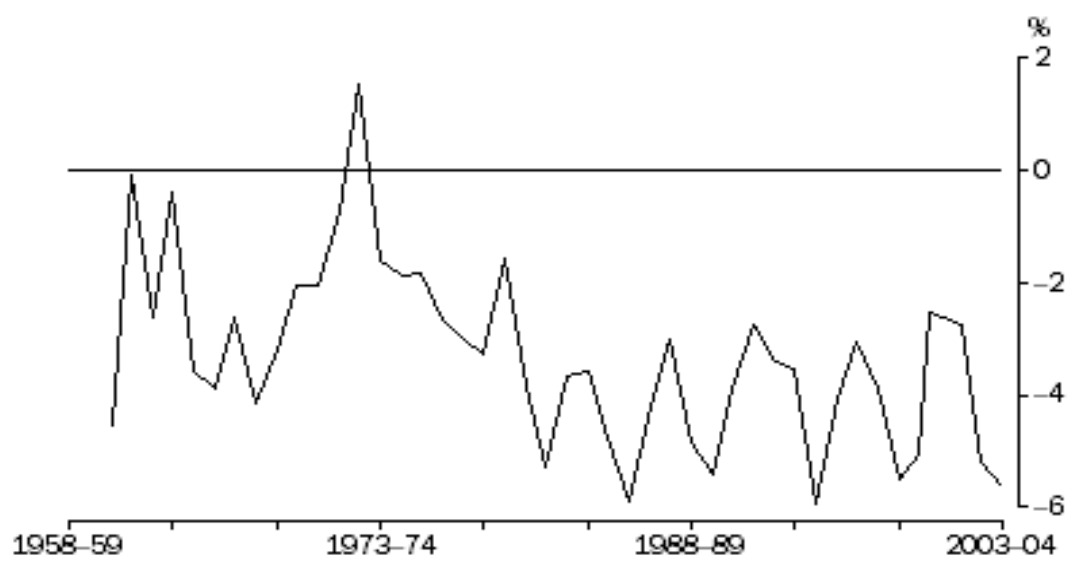

Figure 4. Net Lending to Overseas-relative to GDP. Source: Reference [14].

borrowing from overseas reached 5.6\% in 2003-04, the highest ratio since 1994-95. Together with the information displayed in Figure 4 that the main borrowers in recent years are households and non-financial corporations, we can conclude that some households may borrow indirectly from overseas.

The Australian household sector itself may be an important funding source. A glimpse of the household debt data in 2003-2004 convinces one of the important functions of this funding source. The gross household debt increased by about $15 \%$ of GDP in the financial year 2003-2004 (calculated by author), but the household net borrowing from other sectors increased only around $6.3 \%$ of GDP at the same period (see Figure 3). So, more than half of gross household debt is financed by households themselves.

\section{An Empirical Model}

The direct reasons for rising Australian household debt stem from households' decisions to take on debt. However, the household decision on borrowing and thus the aggregate household debt is ultimately determined by the macroeconomic environment. In this study, we explode the influence of macroeconomic environment on Australian household debt.

\subsection{Model Specification}

The household debt level is jointly determined by supply and demand. The demand for debt is subject to the level of household disposable income and the purposes of borrowing. Household disposable income is derived through household gross income plus social transfer, and less income tax payable and other outlays. At the macro level, these factors can be approximated by GDP. The purposes of household borrowing include smoothing consumption and investing. The level of consumption is closely related to Australian population and the price level (CPI), and may be also related to the macros affecting consumer confidence such as unemployment rate and GDP. The investment decisions are typically related to interest rates. Moreover, from the decomposition of Australian household debt, we learnt that the housing is the main investment vehicle 
for Australian households. In considering the large amount of housing debt, housing prices and the number of new houses entering the market are important factors.

In regards to supply of credit, the availability of funding and the ease of obtaining finance are largely indicated by interest rates. However, to reduce credit risk, lenders may take into account factors like household income level and other macroeconomic variables, such as unemployment rate, inflation rate and GDP. Among these factors, the household income level can be approximated by GDP and the inflation rate is a monotonic transformation of CPI. Including all possible explanatory variables and assuming a linear function form yield the following model:

$$
\begin{aligned}
\text { DEBT } & =\mathrm{C}(1)+\mathrm{C}(2) * \mathrm{NDWELL}+\mathrm{C}(3) * \mathrm{HPI}+\mathrm{C}(4) * \mathrm{R}+\mathrm{C}(5) * \mathrm{ER} \\
& +\mathrm{C}(6) * \mathrm{U}+\mathrm{C}(7) * \mathrm{NX}+\mathrm{C}(8) * \mathrm{GDP}+\mathrm{C}(9) * \mathrm{POP}+\mathrm{C}(10) * \mathrm{CPI}+\varepsilon
\end{aligned}
$$

where

DEBT — accumulated household debt;

NDWELL_number of new dwelling commencements;

HPI-housing price index;

$\mathrm{R}$-interest rate;

ER-exchange rate;

$\mathrm{U}$-unemployment rate;

$\mathrm{NX}$ - net exports;

GDP—gross domestic product;

POP-population;

$\mathrm{CPI}-$ consumer price index.

The above equation is estimated using dynamic ordinary least squares (DOLS). This methodology does not require that all the individual time series be integrated of order one, that is I(1), and it improves the efficiency of OLS via a time domain correction. This involves introducing a number of leads and lags of cointegrated I(1) independent variables in first differences into the OLS estimation.

\subsection{Dataset}

The time series data for the model are mainly seasonally adjusted quarterly time series data for 1988Q2-2006Q1. A majority of data were obtained from the Australian Bureau of Statistics (ABS), including data on population, unemployment rates, housing prices, GDP, net exports and the CPI. The data about new dwelling commencements come from the Housing Industry Association (HIA, 2006). The data on household debt, exchange rate and official interest rates are provided by the Reserve Bank of Australia (RBA). Due to different sources and different measurement of data, some data sequences needed to be adjusted before use. Specifically, the dataset in this study is described as follows:

Household debt (DEBT): seasonally adjusted quarterly data, measured in billion A\$, at the end of quarter.

GDP: seasonally adjusted quarterly data, measured in billion A\$. 
Consumer price index (CPI): base year 1989/1990 $=100$.

Housing price index (HPI): CPI on housing 1989/90 $=100$.

Interest rate (R): official interest rate, quarterly averaged monthly data.

Exchange rate (ER): units of foreign currency per A\$, real trade weighted rate, March $1995=100$

Unemployment rate (U): quarterly averaged monthly data.

Net exports: seasonally adjusted quarterly data, measured in billion $\mathrm{A} \$$.

Population (POP): measured in thousand persons, ABS estimated quarterly data. Since the data is available only from June of 1989 onwards, the annual population in 1988 provided by ABS is adopted as the data in June of 1988 and the data from September 1988 to March 1989 is calculated assuming the population growth rate is stable in this period.

Number of New dwelling commencements (NDWELL): measured in thousand dwellings, including all kinds of housing such as units and houses.

\subsection{Model Estimation and Testing}

Since most macroeconomic time series data are non-stationary, unit root tests should be performed. Before formal testing procedures are undertaken the time series data are plotted to allow for visual inspection (see Appendix 1). Most of time series show apparent trends (except NDWELL and ER). Both Augmented Dickey-Fuller (ADF) and Phillips-Perron (PP) tests are performed and the results are listed in Appendix 2. With the exception of DEBT and POP, the PP and ADF tests suggest first order integration for all variables at $5 \%$ level of significance. For DEBT and POP, the ADF test rejects the null hypothesis of non-stationarity of the first-differenced DEBT and POP at $10 \%$ level of significance, but PP test rejects the hypothesis at very high negative $t$-value. Taking into consideration the critique that the $\mathrm{ADF}$ test has low power in low tail tests (reference [19]), DEBT and POP could be considered to be integrated of order one.

Reference [20] argued that structural change may be mistaken for a unit root. Observation of the plotted data sets indicates the possibility of structural changes: DEBT and NX in 2001, HPI and R in 1998, CPI in 1991, GDP in 1990 and U in 1992. The procedure developed by Perron was used to test for structural change and unit root in each of these series. The test results are given in Appendix 3.

The tests confirm the presence of structural changes (the coefficients on the level dummy variables DL are significantly different from zero) but their existence does not alter the ADF and Phillips-Perron tests results (the t-values for $\alpha 1$ are much higher than the values given by Perron at all levels (see Appendix 4). In short, the unit root tests including structural change confirm the results of ADF and Phillips-Perron tests.

Since non-stationary time series are employed, the co-integration test has to be performed. Both Trace and Max-eigenvalue tests are used. In implementing the tests, a deterministic linear trend and intercept are included in the cointegration equation. The trace test suggests eight cointegration equations while the max-eigenvalue test suggests four cointegration equations (see Table 5). 
Table 5. The results of cointegration tests.

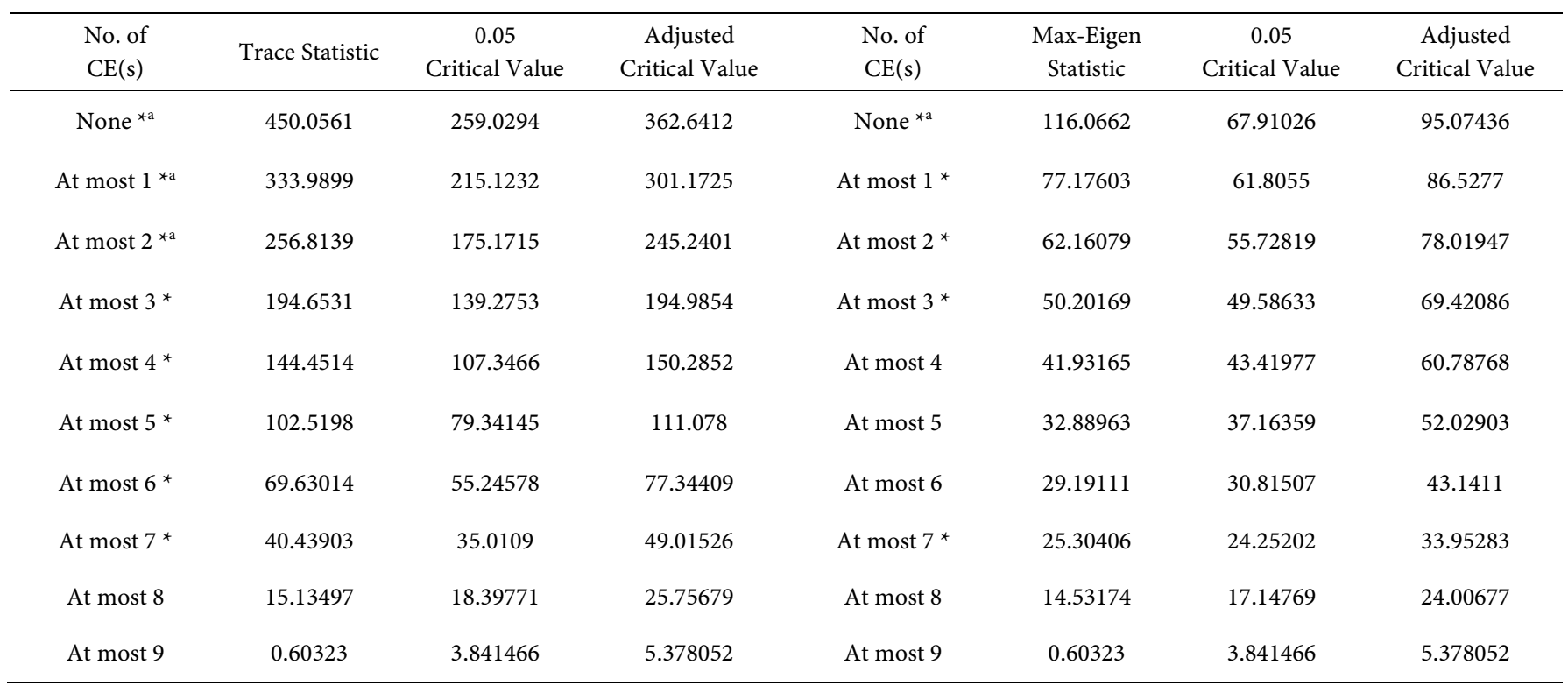

*denotes rejection of the hypothesis at the 0.05 level according to the standard critical value; adenotes rejection of the hypothesis at the 0.05 level according to the adjusted critical value; 2 lags are chosen to minimize SIC.

Since I(1) variables are presented in the model, it is necessary to use DOLS to replace traditional OLS estimation method. The leads and lags in the DOLS are chosen so as to minimize the Schwarz Information Criterion (SIC). The main estimation results are presented in Table 6 (complete estimation results are listed in Appendix 5).

It is not surprising that the Durbin Watson (D.W.) statistic implies the existence of autocorrelation as DOLS allows for a Moving Average (MA) process in the residuals. Since the residuals are auto correlated, the very high adjusted R-squared value is not reliable. However, Stock and Watson (1993) demonstrates that the DOLS estimators have large-sample chi-squared distributions and thus the Wald test is applicable. Therefore, the above standard errors and the $\mathrm{p}$-values from Wald tests are valid.

The estimated model passes the J.B. normality test (see Appendix 6) and the ARCH heteroscedasticity test for up to 10 lags (e.g. $F(10,58)=0.4597, p=0.9075)$. Recursive tests applied to the residuals and coefficients respectively. The recursive residuals are outside the 5\% boundary between 1999 and 2001 (see Appendix 7) and most of the recursive coefficients of the level variables have a big jump (up or down) around year 2000 (see Appendix 8).

The estimated new model passes all diagnostic tests, so the estimation results are accepted. The results in Table 7 show that the structural change dummy variable DT00 are significant at less than $1 \%$ level, which confirms the result of the Chow break point test. Comparing the Wald statistics and p-value in Table 7 and those in Table 6, we found that most variables become more significant, except GDP and POP; notably the significance of NDWELL increases from $10 \%$ level to around 5\% level due to the introduction of the dummy variable DT00. However, the signs of the coefficients remain unchanged. 
Table 6. The preliminary results of DOLS estimation (DEBT as the dependent variable).

\begin{tabular}{|c|c|c|c|c|c|c|c|c|c|c|}
\hline Variable & Constant & NDWELL & HPI & $\mathrm{R}$ & ER & $\mathrm{U}$ & NX & GDP & POP & CPI \\
\hline S.E. & 498.05 & 0.33 & 1.06 & 4.84 & 0.22 & 2.85 & 0.82 & 0.37 & 0.03 & 1.68 \\
\hline Wald Stat. & 10.23 & 2.63 & 11.48 & 4.79 & 14.41 & 9.13 & 8.48 & 626.94 & 15.87 & 13.17 \\
\hline $\mathrm{p}$-value & 0.0014 & 0.1047 & 0.0007 & 0.0287 & 0.0001 & 0.0025 & 0.0036 & 0 & 0.0001 & 0.0003 \\
\hline
\end{tabular}

Table 7. The result of DOLS estimation including structural change (DEBT as the dependent variable).

\begin{tabular}{|c|c|c|c|c|c|c|c|c|c|c|c|}
\hline Variable & Constant & NDWELL & HPI & $\mathrm{R}$ & ER & $\mathrm{U}$ & $\mathrm{NX}$ & GDP & POP & CPI & DT00 \\
\hline Coefficient & 1272.42 & -0.61 & 4.31 & -11.81 & 0.97 & 8.67 & -3.06 & 8.88 & -0.09 & -8.02 & 13.86 \\
\hline S.E. & 473.38 & 0.30 & 1.01 & 4.49 & 0.21 & 2.63 & 0.79 & 0.38 & 0.03 & 1.69 & 4.87 \\
\hline Wald Stat. & 7.23 & 4.05 & 18.26 & 6.92 & 21.62 & 10.87 & 14.85 & 559.64 & 9.68 & 22.45 & 8.11 \\
\hline $\mathrm{p}$-value & 0.0072 & 0.0441 & 0.0000 & 0.0085 & 0.0000 & 0.0010 & 0.0001 & 0.0000 & 0.0019 & 0.0000 & 0.0044 \\
\hline \multicolumn{12}{|c|}{ R-squared $=0.9997$, adjusted R-squared $=0.9996$, D.W. $=1.7497$} \\
\hline
\end{tabular}

\section{Determinants of Australian Household Debt}

Table 7 shows that all displayed factors have significant effects on Australian household debt. Among them, the GDP has the most influential effect (indicated by its large Wald statistic) while NDWELL has the least effect (at around 5\% level of significance). All other variables are significant at less than $1 \%$ level. Based on the characteristics of these variables, we discuss them in 5 groups.

\subsection{The Number of New Dwelling Approvals and Housing Prices}

The housing price index has a significant positive effect on household debt. This significance is easily understood considering the importance of housing prices in housing assets and the importance of housing assets in household debt. The hike of housing prices will scale up the housing assets. For new home buyers, this means they have to take substantially more debt to buy housing, other things being equal. For those who have already taken housing loans, the increased housing assets provide them a good opportunity to withdraw housing equity-obtain more loans against the increased value of housing. As a result, household debt will increase along with the housing prices.

The number of new dwellings also has significant but negative influence. The effects of new dwellings are two-fold. On one hand, the new dwellings increase the total housing assets in the market. Given the high demand for housing and the popularity of housing mortgage loans in Australia, this implies more housing debt for households. On the other hand, the new dwellings entering the market means more housing supply. If the housing demand is unchanged, the housing prices will drop. The decreased housing prices will reduce the market value of housing assets and thus reduce the amount of housing loans accordingly. The estimated results show that the latter effect 
dominates the former.

However, the significant effect of the number of new dwelling approvals should be interpreted together with the land-use policy of Australian governments in the period in our study. Australian state governments had very tight control of the use of land in recent decades, so the number of new dwelling approvals has barely changed-it has fluctuated around 38 thousands per quarter during 1988-2006. The small number of new dwelling commencements made its influence on increased total housing value unimportant, so the price effect dominates. It is possible that with governments loosening their control of the use of land, the effect of the number of new dwellings will become insignificant or even positive.

\subsection{Interest Rate, Unemployment Rate and CPI}

The model shows that the official interest rate has a very significant negative effect on household debt. The interval estimates show that if the official interest rate increases by one percent, the household debt level would decrease by $\$ 7.32-16.30$ billion over time. The direct reason for this is that an interest rate hike will increase the borrowing cost which will deter households from borrowing or at least reduce the amount of money they are inclined to borrow. Moreover, for households who have already incurred debt, it may increase the repayment burden if the debt is based on a variable interest rate (which is the case for most Australian housing loans). If the repayment burden is unbearable, some households are required to sell their property to pay off their debt. As a result, household debt will decrease. The increase in interest rates also indirectly affects household debt by discouraging investment. The reduction in investment will slow down the whole economy. The scaling back of the economy may reduce households' income, increase the financial constraint on households and thus reduce household borrowing. If households' newly incurred debt is less than the amount of their scheduled repayments, the household debt level will decrease.

CPI also shows significant negative effect on household debt. Inflation has different effects on both borrowing and lending sides. On the borrowing side, inflation (increase in CPI) will devalue the debt so it is a strong stimulus for households to borrow. However, on the supply side, inflation will erode the principal and discourage lending. The significant negative effect of CPI indicates that the supply side dominates: in the face of high inflation, fewer funds are lent, so household debt would decrease. This finding is consistent with previous research. For example, many papers (e.g. references [9] [10] [12]) suggest that the low inflation could be a reason for rising household debt because it may decrease the financial constraints on households (lower inflation leads to lower interest rates and thus less income is needed for the reduced scheduled payment) and encourage lending (lower inflation erodes principal more slowly).

The unemployment rate has a significant positive effect on household debt. This positive effect may be the result of the following two facts. One is that the influence of the unemployment on household debt is twofold. On one hand, the high unemployment rate means there is less income for all households and thus a greater desire for loans. 
From this point of view, it will lead to the rise in household debt. On the other hand, the lower income due to unemployment casts doubt on the future income, so the joblessness of households increases the possibility of financial constraints. Consequently, the household debt may shrink. The estimation results suggest the former may overpower the latter. The other fact is that the high unemployment rate tends to associate with the low official interest rate given the RBA interest rate policy. Under this circumstance, the negative effect of unemployment may be overshadowed by that of the official interest rate. This is especially true when we think about the fact that "the degree of overlap between those households with a higher risk of unemployment and those with high debt level has historically been low" (reference [12], p.57). In a period of high unemployment (and low interest rates), the household who are able to borrow may take advantage of low interest rates so that they take on more debt.

\subsection{Exchange Rate and Net Exports}

The negative effect of net exports points to the influence of foreign capital inflow on household debt. Consulting the graph of Australian net exports (see Appendix 1), we find that Australian exports are negative and have a trend becoming more negative in the displayed periods. So the negative effect of net exports on household debt can actually be read as a positive effect of net imports. The increased net importation in the current account needs to be funded by increased supply of foreign exchange in the capital account, which implies the necessary capital inflow in the Australian capital account. By this reasoning, the deteriorated trade balance means an increased net borrowing from foreign countries. Part of this borrowing is done directly or indirectly by Australian households, so the increased net importation will positively affect Australian household debt.

The positive effect of the exchange rate can be readily explained by the foreign capital inflow as a major funding source of Australian household debt. The behaviour of the exchange rate indicates foreign capital movement. In an open economy under the flexible exchange rate, the foreign exchange inflow in the capital account is used to finance the deficit in current account. Any additional foreign capital inflow will increase the supply of foreign exchange and the demand for domestic currency. The pressure of excess supply of foreign exchange and excess demand for domestic money will push up the exchange rate. In another way round, the increase in the exchange rate in recent years indicates the increase in foreign capital inflow shown in Figure 4. Much of this foreign money becomes the direct or indirect funding source of Australian household debt because, from Figure 3 we know, household sector is the largest domestic borrower in recent years.

\subsection{GDP and Population}

The extraordinary positive influence of GDP on household debt may arise via two channels. One is that the magnitude of GDP indicates the size of the economy and thus the capacity of household borrowing and lending. The higher GDP implies higher in- 
come for households and more profit for firms. With higher income, households would be less credit-constrained. On the other hand, the higher income and profit provide more ability for banks to lend. The other channel may come from household confidence. The growth rate of GDP is a popular indicator of economic development, which makes people more confident so that they feel safe to borrow and lend. With the willingness and ability to borrow in the demand side and to lend in the supply side, the household debt may grow in line with GDP.

The negative effect of national population comes as a surprise. It is generally believed that the population should have a positive effect on household debt because the growth of population is likely to increase the number of households with debt and hence the total household debt level will increase with population. This reasoning is consistent with some previous studies. For example, references [21] and [22] conclude the significant effect of population. However, reference [13] shows that there are considerable variations in the determinants and in the marginal effects of household debt within countries and between countries.

The negative effect of Australian population may be explained by the change of population composition in Australia. The increase in population may increase the total household debt if the percentage of households with debt is increased or unchanged. This condition is not valid in Australia because the age composition of population changed as the Australian population increased, shown in Table 8.

Table 8 displays the obviously aging tendency of the Australian population: the median age increases from 33.7 to 36.6 during 1995-2005. According to life cycle hypothesis (LCH) by Modigliani and Brumberg (1954) and permenant income hypothesis (PIH) by Friedman (1957), those who are most likely to have debts are at their relatively early stage of life-cycle-between 25 - 35. Although the actual numbers of the population in this age decile are unavailable, Table 8 suggests that the percentage of households in this decile tends to decrease: the median age of total population increase beyond 35 years in 1999, which tends to indicate that the percentage of population aged

Table 8. Composition of Australian Population.

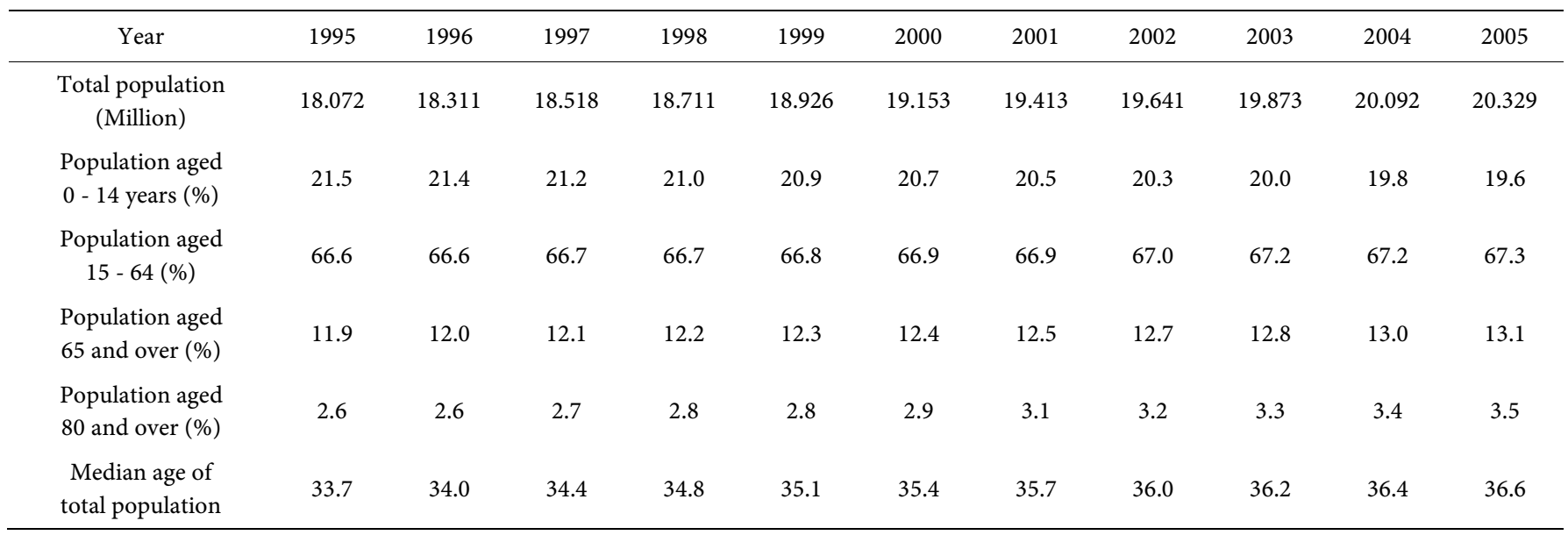

Source: Reference [14]. 
25 - 35 is decreasing. Another fact is that the percentage of population aged 65 and over had increased much faster (1.2\%) than that of population aged $15-64(0.7 \%)$ during the period 1995-2005. According to $\mathrm{LCH}$, people over 65 are unlikely to take on debt (this is also confirmed by the distribution of Australian household debt, see Figure 2). On the contrary, they may bequeath wealth to their children, with which they can pay off their mortgage. In brief, the negative effect of Australian population may be the result of the aging society.

\subsection{Structural Change in 2000}

The positive effect of structural change in 2000 may indicate the impact of the new tax system introduced in 1999. The main reform in the new tax system was the introduction of the goods and services tax (GST) which decreased the purchasing power of household disposable income, perhaps necessitating additional household borrowing and thus increasing the household debt level. More importantly, the Federal Government has implemented a vast array of compensatory policies to help ease the financial burden on households from the introduction of the GST. A number of these policies may have contributed to a rise in household debt. Some examples of these policies include, governmental grants for first-home buyers; tax-exemptions on imputed rental income and capital gains on sales for owner-occupied property; tax deductible expenses for investment housing, such as interest and depreciation; off-setting of capital losses on investments against other income; and capital gains tax on sales of investment housing at half the taxpayer's marginal tax rate. All of these policies tend to reduce the cost of home ownership and encourage households to take on more debt in obtaining housing assets.

Since the September 11 event in 2001 is very close to the time of the structural change in the model and it impacted dramatically on the world economy including Australia, it is arguable that the structural change may be the result of terrorists attacks, instead of the introduction of new tax system. However, with such a structural change the coefficient on the dummy variable DT00 should be negative as households tend to borrow less when economic expectations and levels of confidence are falling. The estimated positive coefficient of DT00 shows the terrorist attacks in 2001 are not responsible for the structural change in the model.

\section{Conclusions}

The DOLS estimation results reveal factors affecting Australian household debt. The growing GDP as an indicator of the increased size of Australian economy has tremendous positive influence, but the increased Australian population which is also associated with the size of the economy is found to have a negative effect due to the changed population structure. The rapidly rising housing prices as indicators of the booming housing market account for much of the increase in Australian household debt while the number of new dwellings affects Australian household debt negatively. The favourable macroeconomic environment manifest in low interest rates and low 
CPI facilitates the surge of Australian household debt, but the unemployment rate is found to act positively. The enormous foreign capital inflow implied by both the hike of the exchange rate and the more negative net exports contributes to the rise in Australian household debt positively. The introduction of new tax system and associated compensation package are found to have promoted Australian household debt significantly.

The rapidly rising household debt may stimulate economic growth by increasing aggregate demand while the slowing down of growth of household debt can contract the economy. This function of household debt can be used to smooth the growth of the economy: encouraging or discouraging household borrowing at proper phases of economic growth. However, since the rising household debt tends to result in economic instability in the long run, it is desirable to rein in the rapidly rising household debt.

\section{References}

[1] The Economist (2003) Finance and Economics: Living in Never-Never Land; Economics Focus. The Economist, London, Vol. 366, 70.

[2] ABC (Australia Broadcasting Corporation) (2003) Lateline Program. http://www.abc.net.au/lateline/content/2003/s907874.htm

[3] ANZ Bank (2005) Submission to the Senate Economic References Committee Public Inquiry.

[4] Bray, J. (2001) Hardship in Australia: An Analysis of Financial Stress Indicators in the 1998-99 Australian Bureau of Statistics Household Expenditure Survey. Department of Family and Community Services Occasional Paper No. 4.

[5] La Cava, G. and Simon, J. (2003) A Tale of Two Surveys: Household Debt and Financial Constraints in Australia, Reserve Bank of Australia, Research Discussion Paper, 2003-08, July 2003.

[6] Schwartz, C., Hampton, T., Lewis, C. and Norman, D. (2006) A Survey of Housing Equity Withdrawal and Injection in Australia, RBA Research Discussion Papers RDP 2006-08.

[7] Stevens, G. (1997) Some Observations on Low Inflation and Household Finances. Reserve Bank of Australia Bulletin, 38-47.

[8] RBA (Reserve Bank of Australia) (1999) Consumer Credit and Household Finance, Reserve Bank of Australia Bulletin.

[9] RBA (Reserve Bank of Australia) (2003) Household Debt: What the Data Show, Reserve Bank Bulletin, March 2003.

[10] The Treasury, Australian Government (2005) Treasury Submission to Senate Economics References Committee Public Inquiry. http://www.treasury.gov.au/documents/710/

[11] Wilson, S. and Turnbull, N. (2000) Australia's Secret Keynesianism. http://www.australianreview.net/digest/2000/08/wilson_turnbull.html

[12] Debelle, G. (2004) Household Debt and the Macroeconomy. BIS Quarterly Review, 51-64.

[13] Crook, J. (2003) The Demand and Supply for Household Debt: A Cross Country Comparison, Credit Research Centre Working Paper, No. 1.

[14] ABS (Australian Bureau of Statistics) (2008) Various Statistic Tables. http://www.abs.gov.au/ausstats/abs@.nsf/webpages/statistics

[15] Macfarlane, I. (2003) Do Australian Households Borrow Too Much? Reserve Bank of Australia Bulletin, 7-16. 
[16] RBA (Reserve Bank of Australia) (2008) Various Statistics Tables.

http://www.rba.gov.au/Statistics

[17] Headey, B. and Wooden, M. (2005) Income, Wealth and Joblessness: Insights from the HILDA Survey. 2005 Melbourne Institute Economic and Social Outlook Conference, 31 March-1 April 2005.

[18] AMP (2004) Household Debt in Australia. AMP Natsem Income and Wealth Report Issue 9. http://www.amp.com.au/ampnatsemreports

[19] Enders, W. (1995) Applied Econometric Time Series. John Wiley \& Son, Inc. USA.

[20] Perron, P. (1989) The Great Crash, the Oil Price Shock, and the Unit Root Hypothesis. Econometrica, 57, 1361-1401. http://dx.doi.org/10.2307/1913712

[21] Tudela, M. and Young, G. (2005) The Determinants of Household Debt and Balance Sheets in the United Kingdom, Bank of England Working Paper No. 266.

[22] Thaicharoen, Y., Ariyapruchya, K. and Chucherd, T. (2004) Rising Thai Household Debt: Assessing Risk and Policy Implications, Bank of Thailand Discussion Paper.

http://www.bot.or.th/BOTHomepage/DataBank/Econcond/seminar/yearly/9-14-2004-Engi-12/paper1.pdf 
Appendix 1. Graphs of Time Series

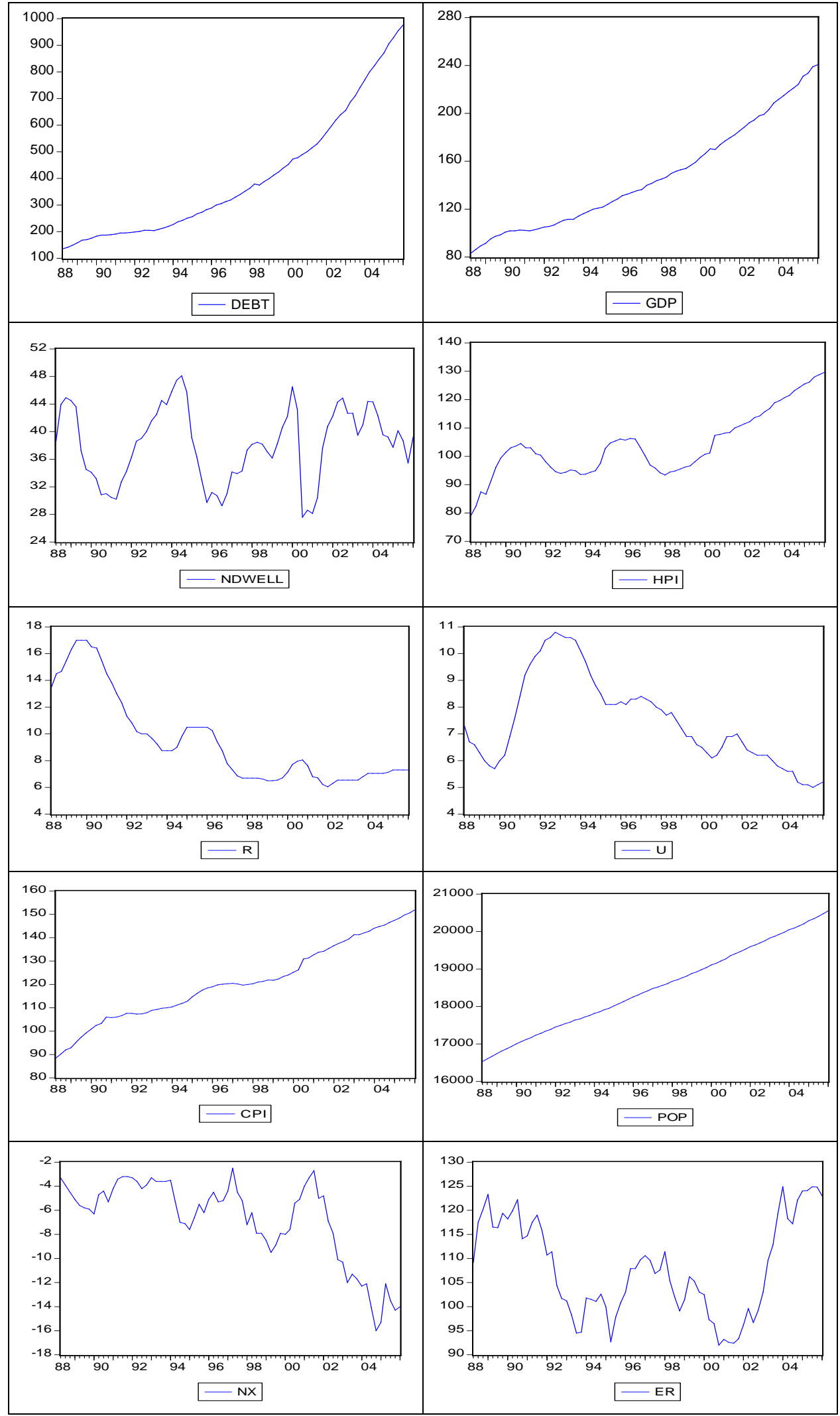


Appendix 2. The Results of Unit Root Tests*

\begin{tabular}{|c|c|c|c|c|c|}
\hline Variable & Level of test & $\begin{array}{l}\text { t-statistics } \\
\text { (ADF test ) }\end{array}$ & $\begin{array}{l}\text { Conclusion of ADF } \\
\text { test ( } 5 \% \text { level) }\end{array}$ & $\begin{array}{c}\mathrm{t} \text {-statistics } \\
\text { (Phillips -Perron } \\
\text { test) }\end{array}$ & $\begin{array}{c}\text { Conclusion of } \\
\text { Phillips-Perron test }\end{array}$ \\
\hline \multirow{2}{*}{ DEBT } & Level & 4.24 & unit root & 3.51 & unit root \\
\hline & First difference & -3.32 & No unit root $(10 \%)$ & -6.06 & No unit root \\
\hline \multirow{2}{*}{ GDP } & Level & 1.45 & unit root & 1.49 & unit root \\
\hline & First difference & -8.02 & No unit root & -8.02 & No unit root \\
\hline \multirow{2}{*}{ NDWELL } & Level & -1.72 & unit root & -1.95 & unit root \\
\hline & First difference & -4.82 & No unit root & -4.78 & No unit root \\
\hline \multirow{2}{*}{ HPI } & Level & -1.72 & unit root & -1.95 & unit root \\
\hline & First difference & -4.82 & No unit root & -4.78 & No unit root \\
\hline \multirow{2}{*}{$\mathrm{R}$} & Level & -2.32 & unit root & -1.67 & unit root \\
\hline & First difference & -3.99 & No unit root & -3.96 & No unit root \\
\hline \multirow{2}{*}{ ER } & Level & -1.18 & unit root & -1.24 & unit root \\
\hline & First difference & -4.60 & No unit root & -7.44 & No unit root \\
\hline \multirow{2}{*}{$\mathrm{U}$} & Level & -3.81 & unit root & -1.75 & unit root \\
\hline & First difference & -2.47 & No unit root & -3.85 & No unit root \\
\hline \multirow{2}{*}{ NX } & Level & -1.79 & unit root & -0.84 & unit root \\
\hline & First difference & -3.16 & No unit root & -7.85 & No unit root \\
\hline \multirow{2}{*}{ CPI } & Level & -1.70 & unit root & -2.24 & unit root \\
\hline & First difference & -6.37 & No unit root & -6.65 & No unit root \\
\hline \multirow{2}{*}{ POP } & Level & -0.59 & unit root & -0.65 & unit root \\
\hline & First difference & -3.11 & No unit root $(10 \%)$ & -8.53 & unit root \\
\hline
\end{tabular}

*lags are automatically selected by E-view software to minimize Schwarz criterion. 
Appendix 3. Results of Unit Root Tests with Structural Change*

\begin{tabular}{|c|c|c|c|c|c|c|c|c|c|}
\hline Variable & Items & $\mathrm{T}$ & $\lambda$ & $\mathrm{k}$ & $\alpha_{0}$ & $\mu_{1}$ & $\mu_{2}$ & $\alpha_{2}$ & $\alpha_{1}$ \\
\hline \multirow{3}{*}{ Debt } & Coefficient & 72 & 0.71 & 8 & 57.5992 & 79.4065 & -74.3534 & 4.7782 & 13.6402 \\
\hline & & & & & & & & & \\
\hline & $\mathrm{t}$-value & & & & 3.8937 & 3.3072 & -1.4624 & 6.6699 & 6.7311 \\
\hline \multirow{2}{*}{$\mathrm{R}$} & Coefficient & 72 & 0.54 & 9 & 14.5268 & -0.0852 & -0.3019 & -0.1329 & 2.5288 \\
\hline & $\mathrm{t}$-value & & & & 28.8042 & -0.1166 & -0.1973 & -7.1953 & 4.3809 \\
\hline \multirow{2}{*}{ NX } & Coefficient & 72 & 0.71 & 16 & -2.2868 & -0.6244 & 2.9717 & -0.1056 & 2.5648 \\
\hline & t-value & & & & -3.5943 & -0.7214 & 1.4470 & -5.2306 & 5.7016 \\
\hline \multirow{2}{*}{ HPI } & Coefficient & 72 & 0.54 & 14 & 84.1834 & -9.7963 & 2.1913 & 0.6122 & 3.1770 \\
\hline & $t$-value & & & & 47.5773 & -3.5863 & 0.3957 & 9.1166 & 6.2784 \\
\hline \multirow{2}{*}{ GDP } & Coefficient & 72 & 0.10 & 4 & 63.6211 & -0.8957 & 3.9201 & 1.8040 & 8.5603 \\
\hline & t-value & & & & 8.2599 & -0.1178 & 0.4480 & 13.6744 & 3.4058 \\
\hline \multirow{2}{*}{ CPI } & Coefficient & 72 & 0.15 & 6 & 90.7220 & 0.5554 & 2.1259 & 0.7632 & 2.4436 \\
\hline & $\mathrm{t}$-value & & & & 61.4758 & 0.3886 & 0.8591 & 43.2699 & 3.4969 \\
\hline \multirow{3}{*}{$\mathrm{U}$} & Coefficient & 72 & 0.21 & 8 & 7.6969 & 4.2986 & -1.0096 & -0.0970 & 2.2965 \\
\hline & & & & & & & & & \\
\hline & t-value & & & & 36.9812 & 13.7334 & -1.4204 & -17.4201 & 6.6533 \\
\hline
\end{tabular}

${ }^{*}$ Model for test: $Y_{T}=\alpha_{0}+\mu_{1} * D_{L}+\mu_{2} * D_{P}+\alpha_{2} * T+\alpha_{1} * Y_{T-1}+\sum_{i=1}^{k} \beta_{i} * d\left(Y_{T-i}\right)+\varepsilon_{T} . \mathrm{k}$ is chosen so that the $\mathrm{p}$-value on $\mathrm{B}_{\mathrm{k}}$ is more than 0.05 in absolute value and, for $i>k$, p-value on $\mathrm{B}_{\mathrm{i}}$ is less than 0.05 .

Appendix 4. Critical t-Values for Structural Change Tests

\begin{tabular}{|c|c|c|c|c|c|c|c|c|c|}
\hline$\lambda=$ & 0.1 & 0.2 & 0.3 & 0.4 & 0.5 & 0.6 & 0.7 & 0.8 & 0.9 \\
\hline $1 \%$ & -4.38 & -4.65 & -4.78 & -4.81 & -4.90 & -4.88 & -4.75 & -4.70 & -4.41 \\
\hline $2.5 \%$ & -4.01 & -4.32 & -4.46 & -4.48 & -4.53 & -4.49 & -4.44 & -4.31 & -4.10 \\
\hline $5 \%$ & -3.75 & -3.99 & -4.17 & -4.22 & -4.24 & -4.24 & -4.18 & -4.04 & -3.80 \\
\hline $10 \%$ & -3.45 & -3.66 & -3.87 & -3.95 & -3.96 & -3.95 & -3.86 & -3.69 & -3.46 \\
\hline $90 \%$ & -1.44 & -1.60 & -1.78 & -1.91 & -1.96 & -1.93 & -1.81 & -1.63 & -1.44 \\
\hline $95 \%$ & -1.11 & -1.27 & -1.46 & -1.62 & -1.69 & -1.63 & -1.47 & -1.29 & -1.12 \\
\hline $97.5 \%$ & -0.82 & -0.98 & -1.15 & -1.35 & -1.43 & -1.37 & -1.17 & -1.04 & -0.80 \\
\hline $99 \%$ & -0.45 & -0.67 & -0.81 & -1.04 & -1.07 & -1.08 & -0.79 & -0.64 & -0.50 \\
\hline
\end{tabular}

Source: Perron (1989) p.1377. 


\section{Appendix 5. Results of DOLS estimation}

Dependent Variable: DEBT

Method: Least Squares

Date: 06/07/09 Time: 18:17

Sample (adjusted): 1988Q4 2005Q4

Included observations: 69 after adjustments

\begin{tabular}{|c|c|c|c|c|}
\hline & Coefficient & Std. Error & $\mathrm{t}$-Statistic & Prob. \\
\hline $\mathrm{C}$ & 1593.225 & 498.0545 & 3.198896 & 0.0027 \\
\hline NDWELL & -0.528233 & 0.325563 & -1.622518 & 0.1124 \\
\hline HPI & 3.581718 & 1.056949 & 3.388735 & 0.0016 \\
\hline $\mathrm{R}$ & -10.59367 & 4.842189 & -2.187786 & 0.0344 \\
\hline ER & 0.839933 & 0.221245 & 3.796394 & 0.0005 \\
\hline $\mathrm{U}$ & 8.600992 & 2.847128 & 3.020937 & 0.0043 \\
\hline NX & -2.390090 & 0.820599 & -2.912614 & 0.0058 \\
\hline GDP & 9.308742 & 0.371774 & 25.03873 & 0.0000 \\
\hline POP & -0.122308 & 0.030701 & -3.983830 & 0.0003 \\
\hline CPI & -6.109054 & 1.683275 & -3.629268 & 0.0008 \\
\hline D(NDWELL(1)) & -0.624961 & 0.339864 & -1.838856 & 0.0732 \\
\hline $\mathrm{D}(\mathrm{HPI}(1))$ & 0.024644 & 1.064469 & 0.023152 & 0.9816 \\
\hline $\mathrm{D}(\mathrm{R}(1))$ & -0.075121 & 3.624836 & -0.020724 & 0.9836 \\
\hline $\mathrm{D}(\mathrm{ER}(1))$ & -0.399003 & 0.239615 & -1.665181 & 0.1035 \\
\hline $\mathrm{D}(\mathrm{U}(1))$ & 5.969554 & 4.535697 & 1.316127 & 0.1954 \\
\hline $\mathrm{D}(\mathrm{NX}(1))$ & -1.292780 & 0.818099 & -1.580224 & 0.1217 \\
\hline $\mathrm{D}(\mathrm{GDP}(1))$ & 5.314939 & 0.703290 & 7.557251 & 0.0000 \\
\hline $\mathrm{D}(\mathrm{POP}(1))$ & 0.038484 & 0.079444 & 0.484416 & 0.6307 \\
\hline $\mathrm{D}(\mathrm{CPI}(1))$ & -0.908136 & 1.814266 & -0.500553 & 0.6194 \\
\hline $\mathrm{D}(\operatorname{NDWELL}(-1))$ & -0.328415 & 0.354325 & -0.926876 & 0.3594 \\
\hline $\mathrm{D}(\mathrm{HPI}(-1))$ & -1.235681 & 0.857383 & -1.441225 & 0.1571 \\
\hline $\mathrm{D}(\mathrm{R}(-1))$ & 8.371518 & 3.621307 & 2.311739 & 0.0259 \\
\hline $\mathrm{D}(\mathrm{ER}(-1))$ & -0.357710 & 0.245861 & -1.454929 & 0.1533 \\
\hline $\mathrm{D}(\mathrm{U}(-1))$ & 10.27233 & 4.706728 & 2.182478 & 0.0349 \\
\hline $\mathrm{D}(\mathrm{NX}(-1))$ & -1.250824 & 0.769740 & -1.624995 & 0.1118 \\
\hline $\mathrm{D}(\mathrm{GDP}(-1))$ & -1.527126 & 0.801560 & -1.905192 & 0.0638 \\
\hline $\mathrm{D}(\mathrm{POP}(-1))$ & 0.143880 & 0.076649 & 1.877126 & 0.0676 \\
\hline $\mathrm{D}(\mathrm{CPI}(-1))$ & 4.754399 & 1.722131 & 2.760766 & 0.0086 \\
\hline R-squared & 0.999723 & \multicolumn{2}{|c|}{ Mean dependent var } & 404.0000 \\
\hline Adjusted R-squared & 0.999540 & \multicolumn{2}{|c|}{ S.D. dependent var } & 227.4913 \\
\hline S.E. of regression & 4.879209 & \multicolumn{2}{|c|}{ Akaike info criterion } & 6.298903 \\
\hline Sum squared resid & 976.0739 & \multicolumn{2}{|c|}{ Schwarz criterion } & 7.205497 \\
\hline Log likelihood & -189.3122 & \multicolumn{2}{|c|}{ Hannan-Quinn criter. } & 6.658579 \\
\hline F-statistic & 5473.378 & \multicolumn{2}{|c|}{ Durbin-Watson stat } & 1.494026 \\
\hline Prob(F-statistic) & 0.000000 & & & \\
\hline
\end{tabular}


Appendix 6. Results of Normality Test

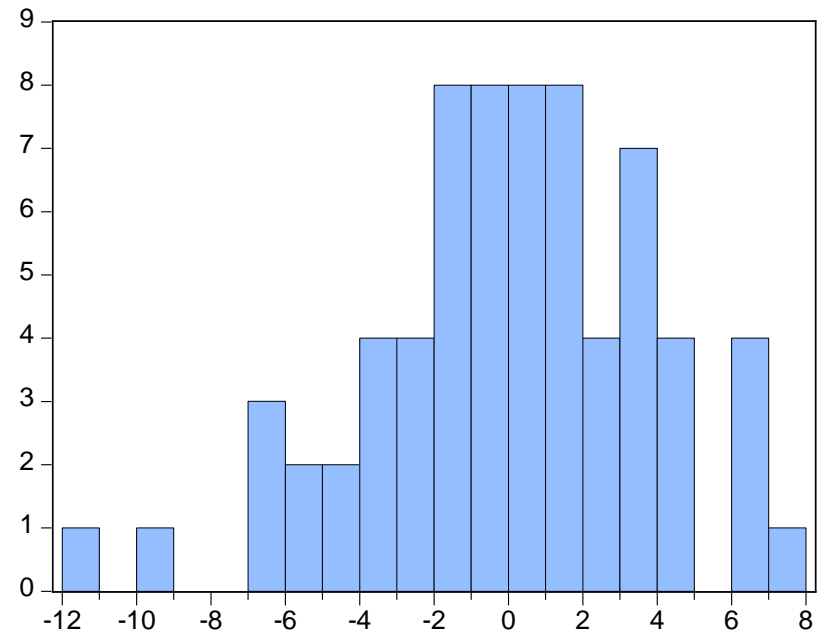

Series: Residuals

Sample 1988Q4 2005Q4

Observations 69

Mean

$-2.22 \mathrm{e}-13$

Median 0.114122

Maximum

7.089493

Minimum $\quad-11.18747$

Std. Dev. $\quad 3.788671$

Skewness $\quad-0.389907$

Kurtosis

3.218241

Jarque-Bera 1.885254

Probability $\quad 0.389603$

\section{Appendix 7. Results of Recursive Residuals Test}

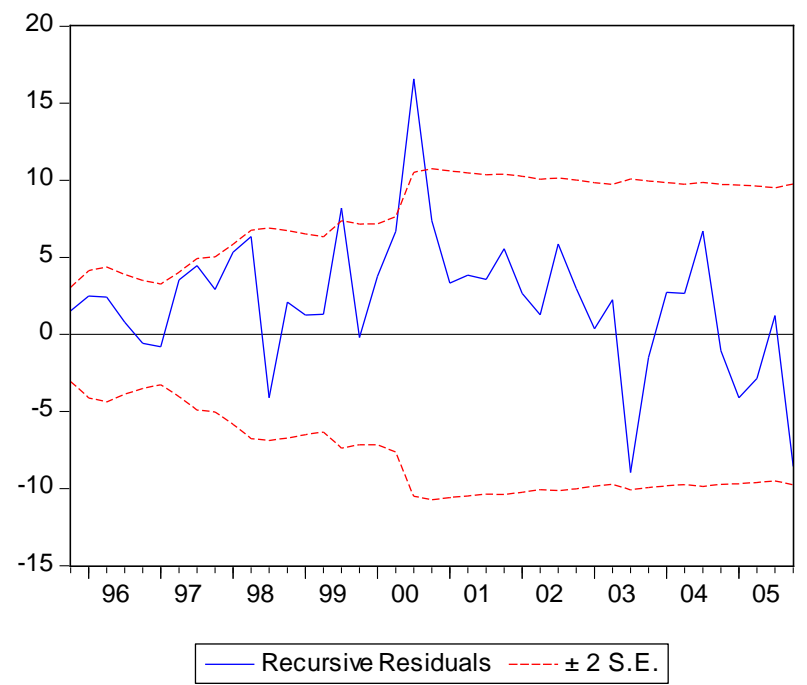




\section{Appendix 8. Results of Recursive Coefficient Tests}

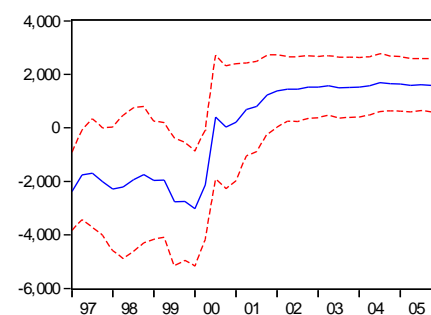

- Recursive C(1) Estimates
--- \pm 2 S.E.

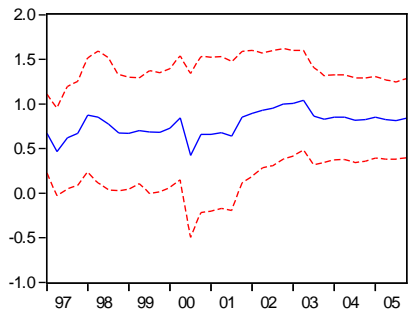

- Recursive C(5) Estimates
--- \pm 2 S.E.

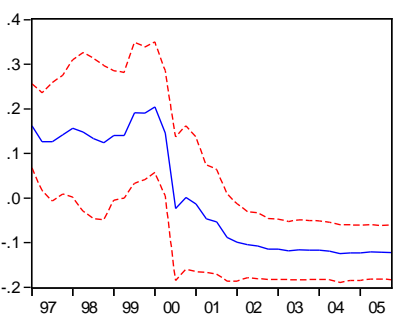

- Recursive C(9) Estimates

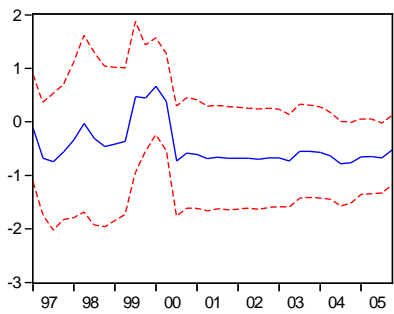

- Recursive C(2) Estimates
--- \pm 2 S.E.

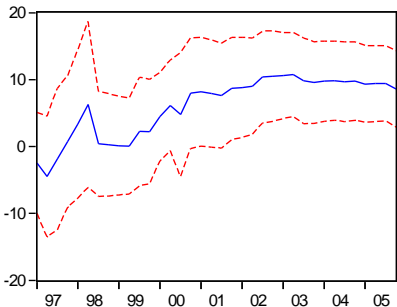

- Recursive C(6) Estimates
--- \pm 2 S.E.

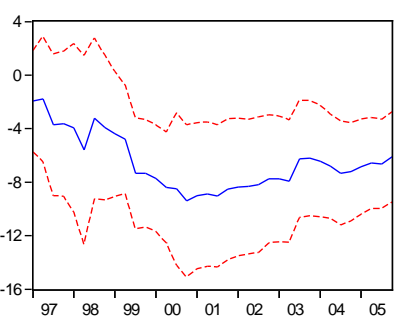

- Recursive C(10) Estimates
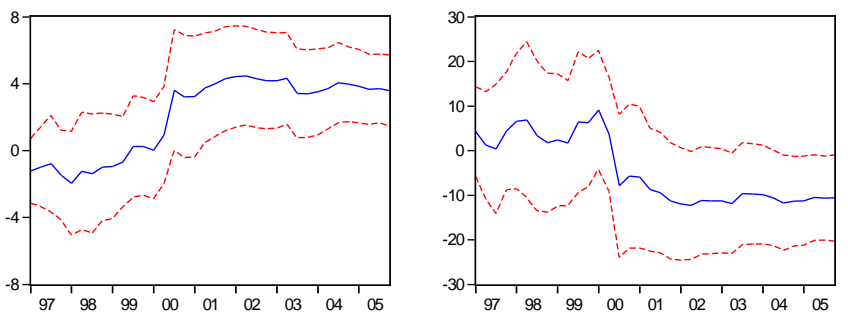

- Recursive C(3) Estimates
---+2 S.

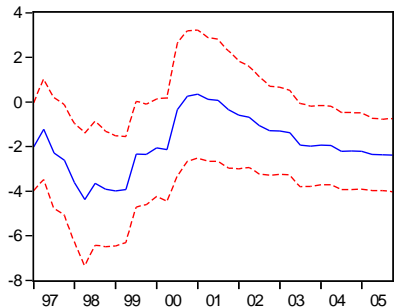

- Recursive C(7) Estimates
--- \pm 2 S.E.
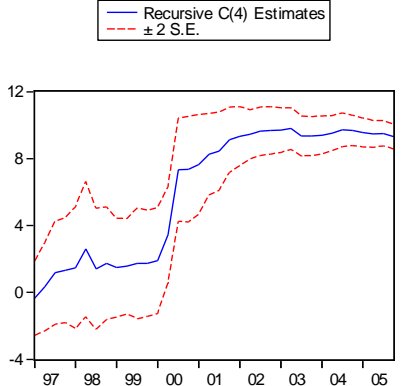

- Recursive C(8) Estimates
-- \pm 2 S.E.
Submit or recommend next manuscript to SCIRP and we will provide best service for you:

Accepting pre-submission inquiries through Email, Facebook, LinkedIn, Twitter, etc.

A wide selection of journals (inclusive of 9 subjects, more than 200 journals)

Providing 24-hour high-quality service

User-friendly online submission system

Fair and swift peer-review system

Efficient typesetting and proofreading procedure

Display of the result of downloads and visits, as well as the number of cited articles

Maximum dissemination of your research work

Submit your manuscript at: http://papersubmission.scirp.org/

Or contact jss@scirp.org 